JEAN NUIA

A third-year UPNG journalism student.

\section{Prize-winning student paper still hangs on}

UNCERTAINTY still clouds the future of the University of Papua New Guinea's award-winning journalism training newspaper Uni Tavur, suspended in the second semester 1997 due to lack of staff and funding.

An edition on October 17 was a special one-off issue with the printing bill sponsored by the Post-Courier, but students, staff and international media organisations have been appealing (see messages on the next pages to the university Vice-Chancellor) for the paper to return as a regular publication.

Students in October collected 1583 signatures supporting the revival of Uni Tavur.

This follows a Journalism Students Society petition to Vice-Chancellor Dr Rodney Hills, an Australian, in April which drew a response that there was little the administration could do.

A former Vice-Chancellor, Joseph Sukwianomb, who was a student leader at UPNG after Uni Tavur was founded in 1974 , is among those who have called for the paper to resume publication and for the university to support it.

'If the administration can afford to buy fancy cars, why can't they afford to fund their very own university student paper?' he told reporter Gorethy Kenneth.

Uni Tavur's founding lecturer, leading New Zealand television journalist Ross Stevens died from cancer in July, aged 50. Another lecturer, who played an important role with the newspaper in the mid-1980s, Peter Henshall, died in 1992, aged 42.

The UPNG journalism program has faced an acute shortage of staff and funding this year. The program has 48 registered students and is being taught and coordinated by one fulltime lecturer.

Students Representative Council president Kevin Kepore appealed to the university to do all it could to retain the newspaper and the journalism program.

He said Uni Tavur had been inter- 
nationally recognised and had a reputation for doing a good job.

'The SRC is willing to back up whatever action the journalism department takes - it is a good cause for the future of both the students and the university,' he added.

The chairperson of the PNG Media Council, Anna Solomon, who is also acting general manager of Word Publishing, has expressed the need for well-trained journalists in the country. She recently told Media Nius that the current staffing crisis was "extraordinary'.

The Media Council recently invited Hills and journalism lecturer David Robie to discuss the future of the program. Such a meeting has not yet taken place.

Hills told Uni Tavur last week that he considered the current student-staff overload as 'absurd'.

He said it was basically a resource problem, saying: 'Get realistic — think about how we are teaching and adjust to the resources.'

Hills added: 'I cannot see the university budget increasing in the next five years.'

In a recent letter, Hills challenged the Media Council by saying: 'The only way journalism can expect to have such specialist staff to teach ... would be if the journalism profession and its related companies were to come forward and agree to fund them from sources external to the university.'

Sorariba Nash, a journalism lecturer currently on leave, responded by saying: "The program is some two decades old and for the Vice-Chancellor to say that is just like saying, "we don't want them".'

Sorariba, once one of the founding students, described the challenge as hypocritical of the university.

'When the New Zealand Government funded the program, the university should have said then that they couldn't afford to fund it and given it to the industry to sustain both funding and the program.'

At present journalism studies is tacked onto the library and information studies department in what is known as the South Pacific Centre for Communication and Information in Development (SPCenCIID).

Concern has been raised by overseas journalism programs and education organisations about journalism at UPNG being integrated with library and information studies - widely regarded as a mismatch.

Journalism lecturer David Robie, who has been the sole fulltime staff person this year, said it was 'hypocrisy and exploitation' when library and information studies had five fulltime lecturers to teach seven courses with a total of 39 students this semester.

One fulltime journalism lecturer coordinates and teaches seven courses with 38 students after a drastic second semester cutback in the program.

Print production and electronic courses were cancelled. 


\section{FORUM}

Over the past few months many international journalism educational and professional groups or individuals have written to UPNG Vice-Chancellor Dr Rodney Hills, appealing for more staff and resources for the Journalism Studies program amid the restructuring of the university. In view of the intense interest in this debate, PJR publishes a selection of the letters.

\section{Electronic reporting}

I WISH to call your attention to the extraordinary and excellent job that staff and students of the journalism program have done in making news of both the University of PNG and the entire nation of Papua New Guinea available to the international community. The online publication of Uni Tavur and Pacific Journalism Review, as well as the maintenance of the Papua Niugini Nius list service, have functioned to deliver important and timely news of current affairs to a wide audience within and beyond the Pacific region.

North American scholars like myself depend on these electronic services (as well as others that David Robie maintains, such as his Café Pacific site) for accurate and professional reporting on events such as the recent national elections and the Sandline crisis. I would regard it as a major loss to UPNG, to the people of Papua New Guinea (including Papua New Guineans living abroad), and to the international community of concerned scholars should the proposed changes in the journalism program terminate these services and the vital journalistic activities that make them possible.

The necessity of budgetary cuts and institutional reorganisation spares no acdemic institution these days. However, such necessities need to be weighed against the obligations of a national university to provide its citizens with the means to participate effectively in a world made ever smaller by the spread of global media.

On a recent trip to PNG I had the opportunity and privilege to collaborate with current students in Journalism Studies. I was impressed with the high quality of their work and their commitment to professional standards of journalism while working under trying conditions with meager resources.

The potential contribution of these students to the future of a free, democratic and informed Papua New Guinea is enormous. Accordingly, I urge you to review and reverse the proposed changes to the journalism program and to support its staff in preparing students for the difficult challenges ahead.

Robert J. Foster

Associate Professor

Department of Anthropology

University of Rochester

Rochester, NY

United States

\section{Call for strong program}

The Journalism school at UPNG has achieved a great deal in recent years and has a high profile within the 
region. It is my understanding that, especially given its size, the school has done very well in preparing students for careers in journalism, as well as providing a locus for the analysis and discussion of significant ongoing issues involving the role of the news media, particularly in the context of developing Pacific nations.

Certainly Australian journalism educators have very great respect for the achievements of David Robie and Sorariba Nash.

Athough not a traditional discipline within universities, Journalism has been taught at some universities in the United States for more than a century, and in some Australian universities for 75 years. There is increasing recognition within the community of the need to provide high quality professional education to journalists in an environment where readers and other media consumers are becoming better eduated and more discriminating, and where governmental and commercial institutions are putting greater resources into attempts at information management.

With all their faults, the news media remain of fundamental significance in any society as disseminators of information and commentary as well as in scrutiny of political and other institutions.

The case for a strong and independent media has as its corollary the existence of strong and independent journalism schools.

Quality news media organisations around the world have come to recognise that on-the-job training for journalists is inadequate, and that contemporary journalists need to be welleducated professionals, with a detailed knowledge of the legal and ethical environments of journalism as well as reporting, interviewing, writing and subediting techniques, investigative skills harnessing emerging technologies, and experience in broadcast as well as print media. UPNG's journalism school is undertaking a unique and essential role, through its media education and analysis, including its pioneering course newspaper, Uni Tavur.

I urge that the journalism school be maintained as a viable and independent unit, with provision of resources to ensure that it can effectively educate tomorrow's journalists and participate in research and media analysis.

\section{Professor John Henningham \\ Department of Journalism University of Queensland Brisbane, Australia}

\section{CJA appeals to uni}

I am writing in the name of the Commonwealth Journalists Association, representing journalists in about 30 Commonwealth countries, to express concern at what appears to be a reduction in size and downgrading in the status of the journalism school at the University of Papua New Guinea.

I refer in particular to reports that the journalism school is being run by 


\section{FORUM}

a single lecturer which must inevitably have an adverse effect on the work of a department which has established a fine reputation for its contribution to the improvement of journalistic standards in your country.

Journalists and journalism educators elsewhere in the Commonwealth have long admired the journalism training provided by the UPNG's journalism department and welcomed its graduates among their ranks.

They have made a notable contribution to our understanding of each other, and many of them have contributed significantly to the good press which Papua New Guinea has hitherto enjoyed overseas.

CJA members in various countries have received Uni Tavur and value its contents. It is widely used as an undergraduate and graduate training tool.

The more recent Niuswire and Pacific Media Watch listserves on the Internet were quoted with approval at the CJA's internatonal conference in Hongkong in January.

They were held up as an example of what journalism students in developing countries can do to help themselves and their country.

We realise that pressures on university funding are causing problems in many countries at the present time but we respectfully suggest that to cut the journalism course at the University of Papua New Guinea or downgrade it in any way could have serious repercussions for the future of jour- nalistic standards in your country and will reflect badly on both the university and the South Pacific area it serves.

May we at least urge you to ensure that sufficient staff are available to give young journalists in Papua New Guinea the training they need.

\section{Lawrie Breen}

Executive Director

Commonwealth Journalists Association

\section{London, United Kingdom}

\section{JEA protest to Hills}

On behalf of the journalism educators of Australia, New Zealand and the Pacific Islands, I write to express our concern over proposed changes to the journalism program at your university.

The journalism education fraternity in the region have long admired the work of our colleagues on the UPNG journalism staff and in particular the quality of the work published in Uni Tavur.

Uni Tavur is a publication well known to journalism educators in the region. In 1995 it won the Journalism Education Association's prized award as the best regular student publication. The judge for the award, then chief executive of the Independent Monthly, Max Suich, described it as head and shoulders above student publications from Australian and New Zealand journalism schools.

Given the critical role Uni Tavur is uniquely placed to play in the current political climate in Papua New 
Guinea, I urge you most strongly to increase the staffing level in journalism from its current one and lift the suspension on the student-produced newspaper.

Roger M. Patching

President

Journalism Education Association Bathurst, Australia

\section{National integrity need}

We write to express our support for journalism teaching at the University of Papua New Guinea and to express some concerns about its future.

We believe that journalism courses at your university have played a role in establishing independent journalism as an important part of the public life of Papua New Guinea.

It was in recognition of the work of SPCenCIID and in particular $\mathrm{Mr}$ David Robie that our own Australian Centre for Independent Journalism began doing joint educational projects with them in 1994. So far, we have participated in publishing Uni Tavur on the World Wide Web, in teaching investigative journalism in Port Moresby and in judging the Pacific Investigative Journalism awards.

We understand that because of a staffing shortage, journalism classes will be cancelled or reduced in the coming semester. In addition, normal student publications such as Uni Tavur will be suspended.

We are also disturbed about a proposal to integrate journalism [courses] with library and information studies.
We have followed similar moves on some of the smaller campuses in the United States where it has caused concern in both academic and professional circles.

We note the recent concerns of the PNG Media Council which pointed to various threats to your country's democratic foundations and the need for 'highly trained journalists with a deep sense of national integrity to take cup the cudgels on behalf of ordnary Papua New Guineans'.

Like the council, we believe that 'training for journalists should not simply involve the mechanics of information dissemination, but should ideally embrace the full spectrum of issues that a working journalist will face in "the real world" - ethics, accountablity, fairness, public duty etc'. Such training is best delivered by properly qualified staff in an environment specifically and separately dedicated to journalism studies.

We hope you will take our views into account when deciding the future of journalism education.

Associate Professor Wendy Bacon Associate Professor Chris Nash David McKnight

Penny O'Donnell

Brenda Mattick

Department of Social Communication and Journalism

University of Technology, Sydney Australia 


\section{UPNG prestige at risk}

I am writing to you in two capacities. First, as newly elected president of the international Commonwealth Journalists Association, a post I assumed in Hongkong in January 1997.

Second, as chairman of the Canadian branch of CJA, which I have headed since 1988. My concern in these two capacities, shared by colleagues here and abroad, is what is happening in journalism in the South Pacific and more particularly university journalism training there.

It seems sadly coincidental with a serious downgrading of priorities in the changes proposed for the journalism school at the University of PNG.

If everyoung professionals needed good training, it's now. If ever a society need the light of good journalism shone upon it, it is PNG now.

UPNG journalism has world standing. It is without peer in delivering the demanding needs of journalism in a developing country.

Thus, to see it now having to abandon its campus newspaper, and cut staff to one lecturer, is a tragedy. It is also an affront to democracy.

The university is recognised as being one of the few in the developing world which applied the value of new technology. It would be a dreadful shame to both the university and the profession to lose it. The prestige of both are in jeopardy.

\section{Murray Burt}

\section{CJA President}

Winnipeg, Canada

160 PACIFIC JOURNALISM REVIEW 4 1997

\section{Development 'model'}

I have twice been invited to UPNG: once in 1989, when the university was unfortunately closed due to some unrest; and in 1995 by the American Embassy and the staff of SPCenCIID and Journalism Studies to deliver seminars and conduct workshops, and consult in the areas of media and television education and curricula.

During my recent visit, I was greatly impressed by what the journalism programs have accomplished under the most challenging circumstances. My experience as a Fulbright Fellow at the University of the South Pacific (Suva 1994) and at the Science University of Malaysia(Penang 1989), along with work as an educator at institutions throughout the region, provide a context from which to share a few observations on UPNG's program in journalism and media.

As the substantial accomplishments of this unique program, and its publication Uni Tavur, have been wellcovered elsewhere, I will simply share my first-hand observations.

While teaching broadcasting in the Journalism Program at USP, I first became aware of Uni Tavur and of the fact that it was superior, not only to our USP student newspaper, but to many student papers at universities in the United States. Top US universities support student publications because they realise that the dissemination of excellent work reflects positively on all academic programs. 
In the case of a developing nation like PNG, professional training in journalism, as well as in broadcast media, directly promotes democratic institutions by raising and reporting on the key issues for an informed electorate. This is the only antidote to the forces of tribalism and superstition which can easily overwhelm the fragile democratic institutions.

UPNG's Journalism Studies, and Uni Tavur in particular, is clearly the most successful and well-managed program of its kind in the South $\mathrm{Pa}$ cific, and also the most visible to my colleagues at American, Australian and New Zealand universities.

\section{Robert Hooper}

\section{Associate Professor}

Department of Communication University of California San Diego, United States.

\section{'The real world'}

At its most recent meeting, the Media Council of PNGnoted with deep concern that the School of Journalism at your university is facing significant restructuring. The Media Council understands the restructuring will mean that the Journalism [program] will be absorbed into the proposed School of Social Sciences and that there will be staff cutbacks. By any definition, this means a dramatic blurring of the focus that the [program] has enjoyed since its inauguration in 1975.

The Media Council is concerned at the implications of these changes on the training and general develop- ment of PNG journalists. Members strongly believe that training for journalists should not simply involve the mechanics of information dissemination, but should ideally embrace the full spectrum of issues that a working journalist will face in 'the real world' - ethics, accountability, fairness, public duty etc.

The council argues that such training can best be delivered by properly qualified staff in an environment specifically and separately dedicated to journalism studies, supported by the mainstream media companies.

The council points out that PNG is facing grave threats to its democratic foundations. There is ample evidence: draft 'media muzzling' legislation which would strike at the very heart of citizens' constitutional rights still lies on the table at Waigani; corruption is rife among politicians and public servants; citizens are dying through lack of basic medical care while the nation's resources are squandered or stolen.

The need has never been greater for highly trained journalists with a deep sense of national integrity to take up the cudgels on behalf of ordinary Papua New Guineans. The council believes this need can best be met by strengthening, rather than weakening, the Faculty of Journalism. The council would welcome an opportunity to discuss this matter further with you.

Max Tomlinson

Secretary

Media Council of PNG

Port Moresby 


\section{FORUM}

\section{Academic friendship}

I am sorry to hear about the devastating drought in the country. I pray for Papua New Guinea and for God's mercyto save further deaths and bring more aid.

I must express my honest congratulations to you all for the wonderful work you guys are doing. I get my updates of PNG from the PJR, Media Nius and Uni Tavur you send to me at my former Flinders University address in Adelaide. I am now at Curtin University of Technology and will appreciate a continuation of your publications.

David and Nash are doing a good job over there and I would like us to continue the good academic friendship. I enjoyed working at the University of Papua New Guinea - although not directly in journalism -- but those journalism students who did my media courses from the Faculty of Creative Arts were good to work with.

Best of luck and regards.

\section{Dr Joe Chika Anyanwu}

School of Communication and Cultural Studies

Curtin University of Technology Perth WA 6845

\section{Australia}

